\title{
Genetic analysis of enteropathogenic Escherichia coli (EPEC) adherence factor (EAF) plasmid reveals a new deletion within the EAF probe sequence among 0119 typical EPEC strains
}

Nathalia B. Teixeira', Thais C. G. Rojas², Wanderley D. da Silveira² ${ }^{2}{\text { Cecília Matheus-Guimarães }{ }^{1} \text {, Neusa P. Silva }}^{3}$ and Isabel C. A. Scaletsky ${ }^{1 *}$

\begin{abstract}
Background: Enteropathogenic Escherichia coli (EPEC) are classified into typical and atypical strains based on the presence of the E. coli adherence factor (EAF) plasmid. The EAF plasmid contains the bfp (bundle-forming pilus) operon and the perABC (plasmid encoded regulator) gene cluster. A 1-kb cryptic region of EAF plasmid has been widely used as a genetic probe for EPEC detection. However, some EPEC strains may harbor an EAF plasmid lacking the EAF probe sequence, which makes the differentiation between typical and atypical a complex task. In this study, we report the genetic analysis of the EAF plasmid-encoded genes in a collection of EPEC clinical isolates.

Methods: A total of 222 EPEC clinical isolates, which were previously classified as typical $(n=70)$ or atypical $(n=152)$ by EAF probe reactivity, were screened for the presence of different EAF sequences by PCR and DNA hybridization.

Results: All typical strains possessed intact bfpA and perA genes, and most of them were positive in the PCR for EAF probe sequence. However, a subset of 30 typical strains, 22 of which belonged to 0119 serogroup, presented a 1652 $\mathrm{pb}$ deletion in the region between 1093-bp downstream perC and 616-bp of the EAF fragment. The bfpA, bfpG, and per genes were found in all typical strains. In addition, 32 (21\%) atypical strains presented the perA gene, and 20 (13.2 \%) also presented the bfpA gene. Among the 32 strains, 16 belonged to the O119:H2, O119:HND, and ONT:HND serotypes. All 32 atypical strains contained perA mutation frameshifts and possessed an IS1294 element upstream of the per operon as detected by PCR followed by restriction fragment length polymorphism (RFLP) typing and multiplex PCR. Among the $20 \mathrm{bfpA}$ probe-positive strains, eight $\mathrm{O} 119$ strains possessed deletion in the bfp operon at the $3^{\prime}$ end of bfpA due to an IS66 element.

Conclusion: Our data show that typical O119 strains may contain a deletion within the EAF probe sequence not previously reported. This new finding suggests that care should be taken when using the previously described EAF PCR assay in epidemiological studies for the detection of typical O119 strains. In addition, we were able to confirm that some atypical strains carry vestiges of the EAF plasmid.
\end{abstract}

Keywords: Enteropathogenic Escherichia coli, EAF plasmid

\footnotetext{
* Correspondence: scaletskyunifesp@gmail.com

'Departamento de Microbiologia, Imunologia e Parasitologia, Universidade Federal de São Paulo, Rua Botucatu, 862, 3 andar, São Paulo 04023-062São Paulo, Brazil

Full list of author information is available at the end of the article
}

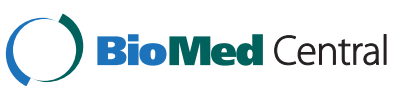

(c) 2015 Teixeira et al. Open Access This article is distributed under the terms of the Creative Commons Attribution 4.0 International License (http://creativecommons.org/licenses/by/4.0/), which permits unrestricted use, distribution, and reproduction in any medium, provided you give appropriate credit to the original author(s) and the source, provide a link to the Creative Commons license, and indicate if changes were made. The Creative Commons Public Domain Dedication waiver (http://creativecommons.org/publicdomain/zero/1.0/) applies to the data made available in this article, unless otherwise stated. 


\section{Background}

Enteropathogenic Escherichia coli (EPEC) are an important cause of infantile diarrhea in developing countries, particularly in Brazil [1-3]. EPEC strains produce a characteristic intestinal histopathology called the attaching-and-effacing (A/E) lesion, which is characterized by microvilli effacement and intimate bacterial adherence to the epithelial membrane. The genes responsible for A/E lesion phenotype are encoded on 35.6-kb chromosomal pathogenicity island known as the locus of enterocyte effacement (LEE). The LEE island comprises approximately 40 genes and encodes the components of a type III secretion system, various effector molecules, and the intimin adhesin which is encoded by the eae gene $[4,5]$.

EPEC strains are classified into typical and atypical based on the presence of the large virulence EPEC adherence factor (EAF) plasmid [6]. The EAF plasmid encodes a type IV fimbria known as the bundle-forming pilus (BFP) that mediate localized adherence (LA) to epithelial cells [7-9]. A 14-gene operon is necessary for BFP production [10], with $b f p A$ encoding the major structural subunit (bundlin). A second operon on the EAF plasmid is the plasmid-encoded regulator (Per), consisting of three genes (perA, perB, and perC genes) [11], which activates genes within the LEE and the $b f p$ operon [12-14].

Additional criteria for classifying isolates as EPEC include the detection of specific serogroups [6]. Classic EPEC O serogroups include O55, O86, O111, O114, O119, O125, O126, O127, O128, and O142. By multilocus enzyme electrophoresis analysis of allelic differences among housekeeping genes, typical EPEC strains have been subtyped into two major lineages, previously designated EPEC1 and EPEC2 $[15,16]$. The EPEC1 includes widespread serotypes such as O55:H6 and O119:H6, whereas EPEC2 consists of serotypes with more limited occurrence such as O111:H2 and O114:H2. Based on a whole-genome phylogeny and analysis of type III secretion system effectors, typical EPEC strains have been demonstrated to cluster in three main lineages, designated EPEC1, EPEC2, and EPEC4 [17]. According to the phylogenomic analyses by Hazen et al. [17] the term atypical EPEC refers to a group of phylogenetically diverse isolates than often are more similar to $E$. coli of other pathovars than EPEC. However, although the term atypical EPEC may be considered misleading, atypical strains are identified by the presence of eae and the absence of the EAF probe sequence as well as the Shiga toxin-encoded genes [6].

A 1-kb cryptic region of EAF plasmid has been widely used as a genetic probe for EPEC detection [18]. However, some EPEC strains, as demonstrated by BFP production, may in fact harbor an EAF plasmid lacking the EAF probe sequence $[19,20]$, which makes the differentiation between typical and atypical complex [21]. Other EPEC strains harbor an EAF plasmid that shares a conserved backbone, and is in many ways similar to pMAR7 plasmid of EPEC1 strain E2348/69 and pB171 plasmid of EPEC2 strain B171, but with inactivating deletions in the $b f p$ and per operons that are required for LA [22, 23]. Such strains are phenotypically "atypical", since they do not produce a typical LA pattern on epithelial cells, even though they carry probe-detectable EAF plasmids. In this study, we report the genetic analysis of the EAF plasmid-encoded genes in a collection of EPEC clinical isolates.

\section{Results and discussion}

In this study, we analyzed a collection of 222 EPEC clinical isolates, including strains of the classic and nonclassic EPEC serotypes, which were previously classified as typical $(n=70)$ or atypical $(n=152)$ by EAF probe reactivity. Initially, all 222 strains were screened for the EAF probe sequence by using a PCR with primers located 100 nucleotides upstream $\left(5^{\prime}\right.$-CGCCATTTATTT TAAGACGAACA) and 82 nucleotides downstream (5' CGCTTCTGCTTTTGACGG) the EAF sequence of pMAR2 [24]. As shown in Tables 1 and 2, the majority of typical strains yielded the expected 1260-bp amplicon. Interestingly no PCR product was obtained from a subset of 30 typical strains, 22 of which belonged to O119 serogroup. To verify this, a new primer located 20 nucleotides upstream perB (5'- GAGCACTCGAAATGAA GAAC) was designed to include the region between perBC and EAF sequence. All 30 typical strains showed a PCR product approximately $1.7-\mathrm{kb}$ smaller than the expected $(3.9 \mathrm{~kb})$. DNA sequencing revealed the presence of a $1652 \mathrm{pb}$ deletion not previously reported, in the region between 1093-bp downstream perC and 616-bp of the EAF fragment. As expected all the atypical strains were PCR-negative.

As shown in Tables 1 and 2, the $b f p A, b f p G$, and per genes, detected by PCR and colony blot hybridization, were present in all typical strains. In addition, 32 (21\%) atypical strains presented the per genes, and 20 (13.2\%) also presented the $b f p A$ gene. Among the 32 strains, 18 strains belonged to the serotypes O119:H2, O119:HND, O142:H2, and ONT:HND atypical strains. Although 20 of 32 strains hybridized with the $b f p A$ probe, $b f p A$ could not be amplified by PCR from eight O119 strains, suggesting that the 3 'end of the gene was deleted and replaced with an IS66-like element as described by Bortolini et al. [22]. To verify this, we carried out PCR with primers targeting the 5 ' end of $b f p A$ and the IS66like element previously described [22]. All the eight O119 strains yielded the expected amplicon, and DNA sequencing confirmed the presence of a 1053-bp IS element inserted into $b f p A$ at position 262 with significant similarity to IS66 (97\%). We evaluated the level of 
Table 1 Results of PCR and hybridization for EAF-encoded genes among typical EPEC strains

\begin{tabular}{|c|c|c|c|c|c|c|c|c|c|c|c|c|c|c|}
\hline \multirow{2}{*}{$\begin{array}{l}\text { Clonal } \\
\text { group }\end{array}$} & \multirow[t]{2}{*}{ Serotype } & \multirow{2}{*}{$\begin{array}{l}\text { No. of } \\
\text { strains }\end{array}$} & \multirow[t]{2}{*}{ Source } & \multicolumn{4}{|c|}{ Presence or absence of: } & \multirow{2}{*}{$\begin{array}{l}\text { IS element } \\
\text { upstream } \\
\text { of per }\end{array}$} & \multicolumn{5}{|c|}{ Presence or absence of: } & \multirow{2}{*}{$\begin{array}{l}\text { perBC-EAF } \\
\text { PCR product }\end{array}$} \\
\hline & & & & $\begin{array}{l}\text { bfpA } \\
\text { (probe) }\end{array}$ & $\begin{array}{l}\text { bfpA } \\
\text { (PCR) }\end{array}$ & $\begin{array}{l}b f p G \\
(P C R)\end{array}$ & $\begin{array}{l}\operatorname{trc} P \\
\text { (probe) }\end{array}$ & & $\begin{array}{l}\text { per } \\
\text { (probe) }\end{array}$ & $\begin{array}{l}\text { perA } \\
\text { (PCR) }\end{array}$ & $\begin{array}{l}\mathrm{EAF} \\
(\mathrm{PCR})\end{array}$ & $\begin{array}{l}\text { orf35-36 } \\
\text { (probe) }\end{array}$ & $\begin{array}{l}\text { orf61-62 } \\
\text { (probe) }\end{array}$ & \\
\hline EPEC1 & O55:H6, NM & 13 & Patients & + & + & + & - & ISI(v६) & + & + & + & + & + & $3.9-\mathrm{kb}$ \\
\hline EPEC1 & O55:NM & 1 & Control & + & + & + & - & ISI(v६) & + & + & + & + & + & $3.9-\mathrm{kb}$ \\
\hline EPEC1 & O86:NM, H34 & 2 & Patients & + & + & + & + & IS1(v६) & + & + & + & + & + & $3.9-k b$ \\
\hline EPEC2 & O111:NM & 5 & Patients & + & + & + & + & ISI(v६) & + & + & + & + & + & $3.9-k b$ \\
\hline EPEC2 & $\mathrm{O} 111: \mathrm{H} 2$ & 4 & Patients & + & + & + & + & ISI(v६) & + & + & + & + & + & 3.9-kb \\
\hline EPEC1 & O119:H6, NM & 16 & Patients & + & + & + & - & ISI(v६) & + & + & - & + & - & $2.2-\mathrm{kb}$ \\
\hline EPEC1 & O119:H6 & 1 & Patient & - & + & + & - & ISI(v६) & - & + & - & + & - & $2.2-k b$ \\
\hline EPEC1 & O119:H6, NM & 5 & Patients & + & + & + & - & ISI(v६) & + & + & - & - & + & $2.2-\mathrm{kb}$ \\
\hline EPEC 1 & O119:H6 & 2 & Controls & + & + & + & + & ISI(v乡) & + & + & + & + & - & $3.9-\mathrm{kb}$ \\
\hline EPEC1 & O119:H6 & 1 & Control & + & + & + & + & ISI(v६) & - & + & + & + & - & $3.9-k b$ \\
\hline EPEC1 & O127:H6, NM & 3 & Controls & + & + & + & - & ISI(v६) & + & + & + & + & - & $3.9-\mathrm{kb}$ \\
\hline EPEC1 & O127:NM & 1 & Patient & + & + & + & - & ISI(v६) & + & + & + & + & - & $3.9-\mathrm{kb}$ \\
\hline Unknown & $\mathrm{O} 2: \mathrm{H} 2, \mathrm{H} 45$ & 2 & Patients & + & + & + & - & ISI(v६) & + & + & + & + & - & 3.9-kb \\
\hline Unknown & O101:H33 & 1 & Control & + & + & + & - & ISI(v६) & + & + & + & + & - & 3.9-kb \\
\hline Unknown & O145:HNT & 1 & Control & + & + & + & - & ISI(v६) & + & + & - & + & - & $2.2-\mathrm{kb}$ \\
\hline Unknown & O162:NM, H33 & 2 & Patients & + & + & + & - & IS1(v६) & + & + & + & + & - & $3.9-\mathrm{kb}$ \\
\hline Unknown & O157:HND & 2 & Patients & + & + & + & - & IS1(v६) & + & + & - & + & - & $2.2-k b$ \\
\hline Unknown & ONT:H45; HND & 3 & Patients & + & + & + & - & ISI(v६) & + & + & + & + & - & $3.9-\mathrm{kb}$ \\
\hline Unknown & ONT:HND & 5 & Patients & + & + & + & - & ISI(v६) & + & + & - & + & - & $2.2-\mathrm{kb}$ \\
\hline EPEC1 & \multicolumn{2}{|c|}{ E2348/69 (O127:H6) } & & + & + & + & - & IS1(v६) & + & + & + & + & + & 3.9-kb \\
\hline EPEC2 & \multicolumn{3}{|l|}{ B171 (O111:NM) } & + & + & + & + & IST(v६) & + & + & + & + & + & $3.9-\mathrm{kb}$ \\
\hline
\end{tabular}

NM Nonmotile; ND Nondetermined; NT Nontypeable 
Table 2 Characteristics of aEPEC strains positive for EAF plasmid-encoded genes either by PCR or hybridization assay

\begin{tabular}{|c|c|c|c|c|c|c|c|c|c|c|c|c|c|}
\hline \multirow[t]{2}{*}{ Strain } & \multirow[t]{2}{*}{ Serotype } & \multirow[t]{2}{*}{ Source } & \multicolumn{4}{|c|}{ Presence or absence of: } & \multirow{2}{*}{$\begin{array}{l}\text { IS element } \\
\text { upstream } \\
\text { of per }\end{array}$} & \multicolumn{5}{|c|}{ Presence or absence of: } & \multirow{2}{*}{$\begin{array}{l}\text { HEp-2 adhesion } \\
\text { pattern }\end{array}$} \\
\hline & & & bfpA (probe) & $b f p A(P C R)$ & bfpA-IS66 & $\operatorname{trc} P$ (probe) & & per (probe) & perA (PCR) & EAF (PCR) & orf35-36 (probe) & orf61-62 (probe) & \\
\hline A103 & O9:HND & Patient & - & - & - & + & 151294 & + & + & - & - & - & - \\
\hline A148 & O37:NM & Patient & - & - & - & - & 151294 & + & + & - & - & - & - \\
\hline A141 & O49:HND & Patient & - & - & - & - & 151294 & + & + & - & + & - & - \\
\hline A69 & O55:NM & Patient & + & + & - & + & 151294 & + & + & - & - & - & LAL \\
\hline A152 & O96:NM & Control & - & - & - & - & 151294 & + & + & - & - & - & - \\
\hline A144 & O98:HND & Patient & - & - & - & + & 151294 & + & + & - & + & - & - \\
\hline A140 & O108:HND & Control & + & - & + & - & 151294 & + & + & - & - & - & LAL \\
\hline A60 & O119:H2 & Patient & + & - & + & - & 151294 & + & + & - & - & - & LAL \\
\hline A62 & $\mathrm{O} 119: \mathrm{H} 2$ & Patient & + & - & + & - & 151294 & + & + & - & - & - & LAL \\
\hline A66 & $\mathrm{O} 119: \mathrm{H} 2$ & Control & + & - & + & - & 151294 & + & + & - & - & - & LAL \\
\hline A67 & O119:H2 & Patient & + & - & + & - & 151294 & + & + & - & - & - & LAL \\
\hline A75 & O119:HND & Patient & + & - & + & - & 151294 & + & + & - & - & - & LAL \\
\hline A90 & O119:HND & Patient & + & + & - & - & 151294 & + & + & - & - & - & LA \\
\hline A111 & O119:HND & Patient & + & - & + & - & 151294 & + & + & - & - & - & LAL \\
\hline A127 & O119:HND & Patient & + & - & + & - & 151294 & + & + & - & - & - & LAL \\
\hline A131 & O119:HND & Patient & + & - & + & - & 151294 & + & + & - & - & - & LAL \\
\hline A97 & O128:HND & Patient & - & - & - & - & 151294 & + & + & - & - & - & - \\
\hline A126 & O128:NM & Patient & - & - & - & - & 151294 & + & + & - & - & - & - \\
\hline A11 & O142:NM & Patient & + & + & - & + & 151294 & + & + & - & + & - & LA \\
\hline A129 & O142:HND & Patient & + & + & - & + & 151294 & + & + & - & + & - & LAL \\
\hline A124 & O157:NM & Patient & - & - & - & - & 151294 & + & + & - & - & - & - \\
\hline A95 & ONT:H21 & Patient & + & + & - & + & 151294 & + & + & - & - & - & LAL \\
\hline A65 & ONT:NM & Control & + & + & - & - & 151294 & + & + & - & - & - & LAL \\
\hline A74 & ONT:NM & Patient & + & + & - & - & 151294 & + & + & - & - & - & LAL \\
\hline A63 & ONT:HND & Patient & + & + & - & - & 151294 & + & + & - & + & + & LAL \\
\hline A64 & ONT:HND & Patient & + & + & - & - & 151294 & + & + & - & + & + & LAL \\
\hline A78 & ONT:HND & Patient & + & + & - & - & 151294 & + & + & - & + & - & LAL \\
\hline A146 & ONT:HND & Control & + & + & - & - & 151294 & + & + & - & + & - & LAL \\
\hline
\end{tabular}


Table 2 Characteristics of aEPEC strains positive for EAF plasmid-encoded genes either by PCR or hybridization assay (Continued)

\begin{tabular}{|c|c|c|c|c|c|c|c|c|c|c|c|c|c|}
\hline A57 & ONT:HND & Patient & - & - & - & - & $1 S 1294$ & + & + & - & - & - & - \\
\hline A16 & ONT:HND & Control & - & - & - & - & 151294 & + & + & - & + & - & - \\
\hline A 118 & ONT:HND & Patient & - & - & - & - & 151294 & + & + & - & - & - & - \\
\hline A136 & ONT:HND & Patient & - & - & - & - & 151294 & + & + & - & + & - & LAL \\
\hline
\end{tabular}


expression of $b f p A$ by RT-PCR in the $20 b f p A$-positive strains. The RT-PCR results showed that the $b f p A$ gene was transcribed only by the strains carrying the intact bfpA gene sequence (Fig. 1). Two of these strains, A90 (O119:HND) and A11 (O142:NM), present the LA pattern. Considering the BFP production as a truly phenotype marker of typical EPEC strains, these strains are in fact typical EPEC rather than atypical EPEC as originally classified by the EAF-probe reactivity.

The EAF plasmids from two well-studied EPEC strains have been sequenced $[25,26]$. The major difference between pMAR7 (E2348/69, EPEC1 lineage) and pB171 (B171, EPEC2 lineage) is the presence of conjugative transfer (tra) genes on pMAR7, absent in pB171 [26]. Apart from the tra region, several other ORFs are present in pB171 but not in pMAR7, such as the region orf35-36 (truncated homolog of the EHEC toxB gene), the region orf61-62 ( $\mathrm{gadB}$ [truncated] and gadC homologs), and the putative chaperonine $\operatorname{trc} P$ located between the $b f p$ and per operons flanked by insertion (IS) elements. As shown in Tables 1 and 2, a subset of typical strains O55, O86, O111 and O119 strains were positive for one or more pB171 derived-probes, while most of atypical EPEC strains did not hybridize with one or more of the probes (Fig. 2).

The sequence of plasmid pB171 reveals that a partial IS1(v६) homolog lies immediately upstream of the per operon [26]. This $\operatorname{IS} 1(v \xi)$ element is replaced by a partial IS1294 in O119:H2 (MB80), O128:H2, and O142:H6 (O142\#15) strains containing perA mutation frameshifts, leading to premature truncation and consequent inactivation of the gene [23]. Okeke et al. [23] developed a multiplex PCR which gives a 650-bp product in strains with the IS1 $(v \xi)$ element and a 500-bp product in strains that have the IS1294, and a SspI-based PCR-RFLP typing which distinguishes normal perA alleles from those with $\mathrm{O} 119: \mathrm{H} 2$, O128:H2, or O142:H6 type-frameshift. As

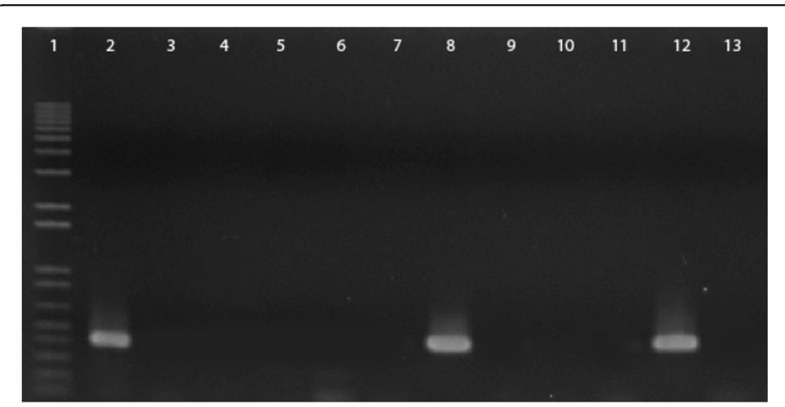

Fig. 1 Agarose gel electrophoresis of the RT-PCR products of 0119 and 0142 atypical EPEC strains. Lane1, 1-kb ladder plus (Gibco, BRL); lane 2, E2348/69 strain (positive control); lane 3, A60 strain; lane 4, A62 strain; lane 5, A66 strain; lane 6, A67 strain; lane 7, A75 strain; lane 8, A90 strain; lane 9, A111 strain; lane 10, A127 strain; lane 11, A131; lane 12, A11 strain; and lane 13, A129 strain shown in Tables 1 and 2, all typical strains yielded a 650-bp product, while all 32 atypical strains with perA mutation frameshifts yielded a 500-bp product. In addition, all typical strains showed a perA RFLP pattern similar to that of control EPEC strain (E2348/69), while all 32 perA probe-positive atypical strains produced a pattern consistent with that of the MB80. The entire perA gene was amplified and sequenced in all 32 atypical strains, and DNA sequencing confirmed the presence of perA mutation identical to that of MB80 strain. These results suggest that the presence of an inactive perA gene could be used to differentiate typical from atypical strains. Interestingly, most strains carrying vestiges of EAF plasmid belong to the same serogroups as typical EPEC, suggesting that these strains may constitute a group of EPEC strains that carry a defective EAF plasmid rather than atypical EPEC isolates.

\section{Conclusion}

Our data show that typical O119 strains, which were the most prevalent isolates in São Paulo, in the past [27], may contain a deletion within the EAF probe sequence not previously reported. This new finding suggests that care should be taken when using the previously described EAF PCR assay [28] in epidemiological studies for the detection of typical O119 strains. In addition, we were able to confirm that some atypical strains carry vestiges of the EAF plasmid [29-31].

\section{Methods}

\section{Strains}

The strains examined in this report were isolated during epidemiological studies of acute diarrhea in children $<2$ years of age conducted in different regions of Brazil in 1999-2009 [2, 32-34]. These strains were identified by colony hybridization with eae and/or EAF probe sequences and serotyped, and most of them had also been characterized by the presence of LEE-associated DNA sequences, and adherence to HEp-2 cells [34, 35]. Strains were grown overnight at $37{ }^{\circ} \mathrm{C}$ in $5 \mathrm{ml}$ of Luria-Bertani broth with shaking. Genomic DNA was isolated using the HiYield Genomic DNA Mini kit (Real Biotech Corporation, Taiwan), and was used as the template for the PCR assays.

\section{Ethics statement}

The study was approved by the ethics committee of the Universidade Federal de São Paulo, Brazil. Stool samples were obtained with the written informed consent from the parents or guardians of the children.

\section{Screening for EAF plasmid genes}

The presence of EAF plasmid-encoded genes was determined by colony hybridization and PCR. Colony 


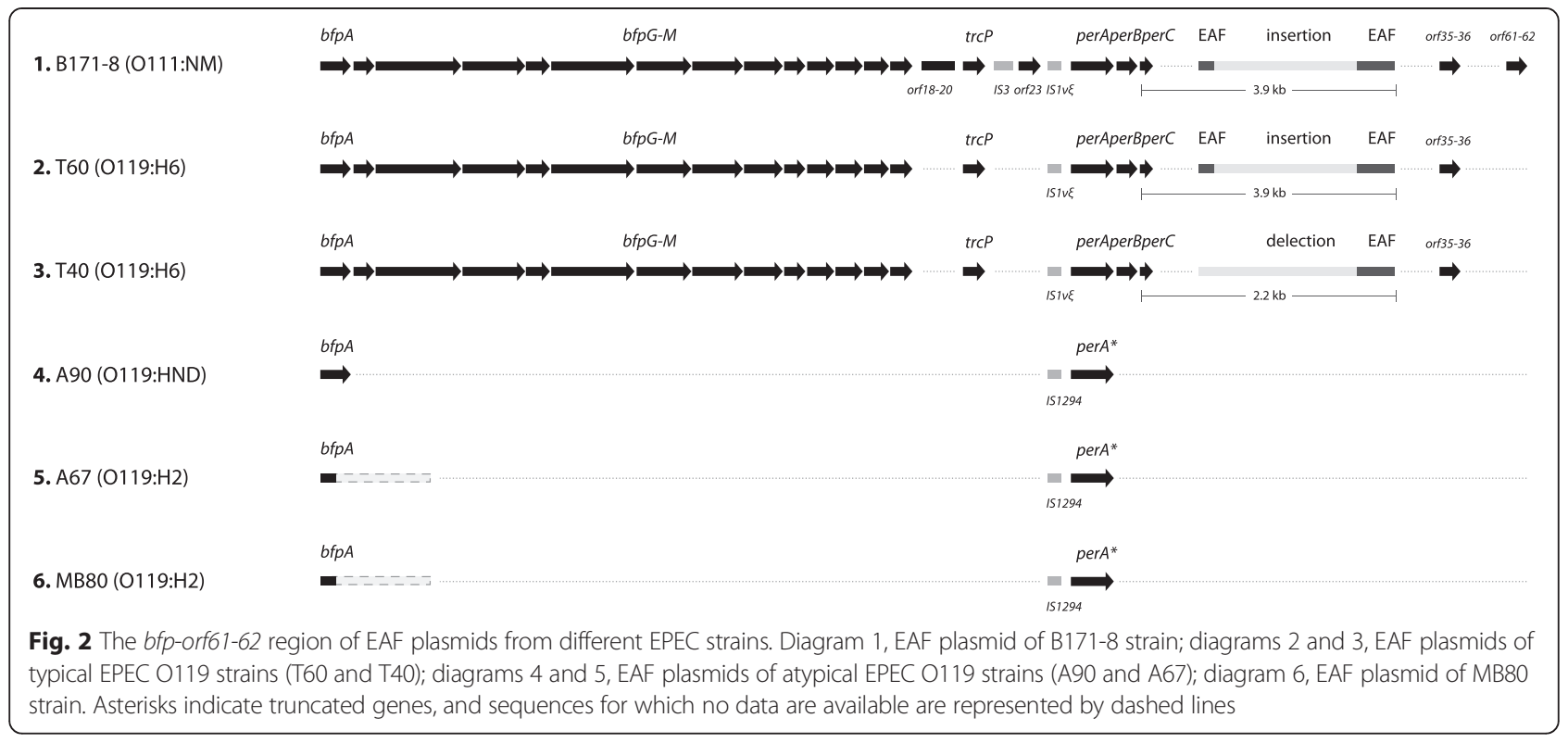

hybridizations were performed under high-stringency conditions at $65{ }^{\circ} \mathrm{C}$ employing probes that were labeled by random priming with $\left[\alpha-{ }^{32} \mathrm{P}\right] \mathrm{dCTP}$ as described previously [32]. Fragments probes for $b f p A$ and per $A B C$, were prepared from plasmid clones as described previously [22]. Probes for $b f p G$, trcP, orf35-36, and orf61-62, were prepared by PCR primers as described [23] using strain B171 as the template. The DNA fragments were purified, labeled with $\left[\alpha-{ }^{32} \mathrm{P}\right] \mathrm{dCTP}$ with a DNA labeling kit (Amersham Pharmacia Biotech Inc., EUA) and used as probes. Blots were hybridized in a solution containing the labeled probe $\left(10^{5} \mathrm{cpm}\right), 5 \times$ standard saline citrate (SSC), $2 \times$ Denhardt's solution (Invitrogen), $0.1 \%$ sodium dodecyl sulfate (SDS), and $5 \mathrm{mg} / \mathrm{ml}$ of salmon sperm DNA for $16 \mathrm{~h}$ at $65{ }^{\circ} \mathrm{C}$. After hybridization, washes were done in aqueous solution with $2 \times$ SSC with $0.1 \%$ SDS and exposed to X-ray film.

The $b f p A$ gene was amplified by PCR with primers bfpA_114F (GTCTGCGTCTGATTCCAATA) and bfpA_ 521R (TCAGCAGGAGTAATAGC) as previously described [36].

The entire perA gene was amplified by PCR with primers K1693 (CCCAAGCTTTGGCAATGTTCCTTG TGT) [23] and perA-24F (AACAAACGCGCATGAA GGTG) [22]. The 770-bp amplicon from perA-positive strains was digested with the restriction enzyme $S s p \mathrm{I}$, and restriction fragment length polymorphism (RFLP) analysis was performed by agarose gel electrophoresis.

The per upstream region to IS1(v६) was amplified by PCR with primers K1547 (TGAGTCACCTCTGCCT GAG) and K1549 (TGGATTCTATTGTGTATTCGG), and the per upstream region to IS1294 was amplified by PCR with primers K1978 (TGTGAGAGCTTCTCAGCA) and K1549 (TGGATTCTATTGTGTATTCGG) as previously described [23].

\section{RNA extraction and RT-PCR assays}

Total RNA was extracted after bacterial growth in LB broth for $18 \mathrm{~h}$ at $37{ }^{\circ} \mathrm{C}$ with the RNase Mini extraction kit (Qiagen) according to the manufacturer's instructions. After extraction, approximately $1 \mu \mathrm{g}$ of total RNA was digested with DNase I (Qiagen) for $30 \mathrm{~min}$ at $37^{\circ} \mathrm{C}$, and the enzyme was then inactivated by adding $1 \mu \mathrm{l}$ of $25 \mathrm{mM}$ EDTA and heating the solution at $65{ }^{\circ} \mathrm{C}$ for 10 min. To obtain the cDNA, the SperScript III One Step RT-PCR System with Platinum Taq DNA polymerase (Invitrogen) was used according to the manufacturer's specifications. Primers for $16 \mathrm{~S}$ ribosomal protein were used to control PCR [37], and the assay was then carried out with primers bfpA_114F (GTCTGCGTCT GATTCCAATA) and bfpA_521R (TCAGCAGGAGTA ATAGC) as previously described [36]. PCR products were analyzed by $1 \%$ agarose gel electrophoresis.

\section{DNA sequencing}

Nucleotide sequencing of the PCR products was performed at the Centro de Estudos do Genoma HumanoUSP, São Paulo. Nucleotide sequence data were analyzed using SeqMan and MegAlign software and the BLAST tool (http://www.ncbi.nlm.nih.gov/BLAST).

\section{Nucleotide sequence and accession number}

The DNA sequences for the EAF region of ypical EPEC O119 strains (T60 and T40) are availability in NCBI database under accession numbers KT595240 and KT819171. 


\section{Abbreviations}

EPEC: Enteropathogenic Escherichia coli; EAF: E. coli adherence factor plasmid; Bfp: Bundle-forming pilus; Per: Plasmid-encoded regulator.

\section{Competing interests}

The authors declare that they have no competing interests.

\section{Authors' contributions}

NBT and CMG performed experiments. TCGR and WDS analyzed data and contributed to the preparation of the manuscript. ICAS designed the experimental procedures, supervised all the experimental works and wrote the manuscript. NPS participated in the design of the experiments and reviewed the paper. All authors read and approved the final manuscript.

\section{Authors' information}

Not applicable.

\section{Acknowledgments}

This study was supported by research grants from Fundação de Amparo a Pesquisa do Estado de São Paulo (FAPESP) and Conselho Nacional de Desenvolvimento Científico e Tecnológico (CNPq).

\section{Author details}

'Departamento de Microbiologia, Imunologia e Parasitologia, Universidade Federal de São Paulo, Rua Botucatu, 862, 3 andar, São Paulo 04023-062São Paulo, Brazil. ${ }^{2}$ Departamento de Genética, Evolução e Bioagentes, Instituto de Biologia, Universidade Estadual de Campinas, Campinas, Brazil. ${ }^{3}$ Disciplina de Reumatologia, Universidade Federal de São Paulo, São Paulo, Brazil.

\section{Received: 4 May 2015 Accepted: 29 September 2015}

\section{Published online: 05 October 2015}

\section{References}

1. Levine MM, Edelman R. Enteropathogenic Escherichia coli of classic serotypes associated with infant diarrhea: epidemiology and pathogenesis. Epidemiol Rev. 1984:6:31-51.

2. Araújo JM, Tabarelli GF, Aranda KR, Fabbricotti SH, Fagundes-Neto U, Scaletsky ICA. Typical enteroaggregative and atypical enteropathogenic types of Escherichia coli are the most prevalent diarrhea-associated pathotypes among Brazilian children. J Clin Microbiol. 2007:45:3396-9.

3. Bueris V, Sircili MP, Taddei CR, Santos MF, Franzolin MR, Martinez MB, et al. Detection of diarrheagenic Escherichia coli from children with and without diarrhea in Salvador, Bahia, Brazil. Mem Inst Oswaldo Cruz. 2007;102:839-44.

4. Finlay BB, Rosenshine I, Donnenberg MS, Kaper JB. Cytoskeletal composition of attaching and effacing lesions associated with enteropathogenic Escherichia coli adherence to HeLa cells. Infect Immun. 1992;60:2541-3.

5. McDaniel TK, Jarvis KG, Donnenberg MS, Kaper JB. A genetic locus of enterocyte effacement conserved among diverse enterobacterial pathogens. Proc Natl Acad Sci U S A. 1995;92:1664-8.

6. Nataro JP, Kaper JB. Diarrheagenic Escherichia coli. Clin Microbiol Rev. 1998:11:142-201.

7. Donnenberg MS, Girón JA, Nataro JP, Kaper JB. A plasmid-encoded type IV fimbrial gene of enteropathogenic Escherichia coli associated with localized adherence. Mol Microbiol. 1992;6:3427-37.

8. Girón JA, Ho AS, Schoolnik GK. An inducible bundle-forming pilus of enteropathogenic Escherichia coli. Science. 1991;254:710-3.

9. Knutton S, Shaw RK, Anantha RP, Donnenberg MS, Zorgani AA. The type IV bundle forming pilus of enteropathogenic Escherichia coli undergoes dramatic alterations in structure associated with bacterial adherence, aggregation and dispersal. Mol Microbiol. 1999:33:499-509.

10. Stone KD, Zhang HZ, Carlson LK, Donnenberg MS. A cluster of fourteen genes from enteropathogenic Escherichia coli is sufficient for the biogenesis of a type IV pilus. Mol Microbiol. 1996;20:325-37.

11. Gómez-Duarte OG, Kaper JB. A plasmid-encoded regulatory region activates chromosomal eaeA expression in enteropathogenic Escherichia coli. Infect Immun. 1995;63:1767-76.

12. Elliott SJ, Sperandio V, Girón JA, Shin S, Mellies JL, Wainwright L, et al. The locus of enterocyte effacement (LEE)-encoded regulator controls expression of both LEE- and non-LEE-encoded virulence factors in enteropathogenic and enterohemorrhagic Escherichia coli. Infect Immun. 2000;68:6115-26.
13. Mellies JL, Elliott SJ, Sperandio V, Donnenberg MS, Kaper JB. The Per regulon of enteropathogenic Escherichia coli: identification of a regulatory cascade and a novel transcriptional activator, the locus of enterocyte effacement (LEE)-encoded regulator (Ler). Mol Microbiol. 1999;33:296-306.

14. Tobe T, Schoolnik GK, Sohel I, Bustamante VH, Puente JL. Cloning and characterization of bfpTVW genes required for the transcriptional activation of bfpA in enteropathogenic Escherichia coli. Mol Microbiol. 1996;21:963-75.

15. Ørskov F, Whittam TS, Cravioto A, Ørskov I. Clonal relationships among classic enteropathogenic Escherichia coli (EPEC) belong to different 0 groups. J Infect Dis. 1990;162:76-81.

16. Whittam TS, McGraw E. Clonal analysis of EPEC serogroups. Rev Microbiol. 1996;27:7-16.

17. Hazen TH, Sahl JW, Fraser CM, Donnenberg MS, Scheutz F, Rasko DA. Refining the pathovar paradigm via phylogenomics of the attaching and effacing Escherichia coli. PNAS. 2013;110:12810-5

18. Nataro JP, Baldini MM, Kaper JB, Black RE, Bravo N, Levine MM. Detection of an adherence factor of enteropathogenic Escherichia coli with a DNA probe. J Infect Dis. 1985;152:560-5.

19. Ghilard ACR, Gomes TAT, Elias WP, Trabulsi LR. Virulence factors of Escherichia coli strains belonging to serogoups 0127 and 0142. Epidemiol Infect. 2003;131:815-21.

20. Gismero-Ordoñez J, Dall'Agnol M, Trabulsi LR, Girón JA. Expression of the bundle-firming pilus by enteropathogenic Escherichia coli strains of heterologous serotypes. J Clin Microbiol. 2002;40:2291-6.

21. Trabulsi LR, Gomes KR, TAT. Typical and atypical enteropathogenic Escherichia coli. Emerg Infect Dis. 2002;8:508-13.

22. Bortoloni M, Trabulsi L, Keller R, Frankel G, Sperandio V. Lack of expression of bundle-forming pili in some clinical isolates of enteropathogenic Escherichia coli (EPEC) is due to a conserved large deletion in the bfp operon. FEMS Microbiol Lett. 1999;179:169-74.

23. Okeke IN, Borneman JA, Shin S, Mellies JL, Quinn LE, Kaper JB. Comparative sequence analysis of the plasmid-encoded regulator of enteropathogenic Escherichia coli strains. Infect Immun. 2001;69:5553-64.

24. Baldini MM, Kaper JB, Levine MM, Candy DC, Moon HW. Plasmid-mediated adhesion in enteropathogenic Escherichia coli. J Pediatr Gastroenterol Nutr. 1983;2:534-9.

25. Brinkley C, Burland V, Keller R, Rose DJ, Boutin AT, Klink SA, et al. Nucleotide sequence analysis of the enteropathogenic Escherichia coli adherence factor plasmid pMAR7. Infect Immun. 2006;74:5408-13.

26. Tobe T, Hayashi T, Han C, Schoolnik G, Ohtsubo E, Sasakawa C. Complete DNA sequence and structural analysis of the enteropathogenic Escherichia coli adherence factor plasmid. Infect Immun. 1999:67:5455-62.

27. Gomes TAT, Griffin PM, Ivey C, Trabulsi LR, Ramos SRT. EPEC infections in São Paulo. Rev Microbiol. 1996:27:25-33.

28. Franke J, Franke S, Schmidt H, Schwarzkopf A, Wieler LH, Baljer G, et al. Nucleotide sequence analysis of enteropathogenic Escherichia coli (EPEC) adherence factor probe and development of PCR for rapid detection of EPEC harboring virulence plasmids. J Clin Microbiol. 1994;32:2460-3.

29. Dulguer MV, Fabbricotti SH, Bando SY, Moreira-Filho CA, Fagundes-Neto U. Atypical enteropathogenic Escherichia coli strains: phenotypic and genetic profiling reveals a strong association between enteroaggregative $E$. coli heat-stable enterotoxin and diarrhea. J Infect Dis. 2003;188:1685-94.

30. Abe CM, Trabulsi LR, Blanco J, Blanco M, Dahbi G, Blanco JE, et al. Virulence features of atypical enteropathogenic Escherichia coli identified by the eae + EAF-negative stx-genetic profile. Diagn Microbiol Infect Dis. 2009;64:357-65.

31. Gomes TAT, Irino K, Girão VBC, Guth BEC, Vaz TMI, Moreira FC, et al. Emerging enteropathogenic Escherichia coli strains? Emerg Infect Dis. 2004;10:1851-5.

32. Scaletsky ICA, Fabbricotti SH, Aranda KR, Morais MB, Fagundes-Neto U. Comparison of DNA hybridization and PCR assays for detection of putative pathogenic enteroadherent Escherichia coli. J Clin Microbiol. 2002:40:1254-8.

33. Scaletsky ICA, Fabbricotti SH, Silva SO, Morais MB, Fagundes-Neto U. HEp-2adherent Escherichia coli strains associated with acute infantile diarrhea, São Paulo, Brazil. Emerg Infect Dis. 2002;8:855-8.

34. Scaletsky ICA, Aranda KR, Souza TB, Silva NP, Morais MB. Evidence of pathogenic subgroups among atypical enteropathogenic Escherichia coli strains. J Clin Microbiol. 2009:47:3756-9.

35. Scaletsky IC, Aranda KR, Souza TB, Silva NP. Adherence factors in atypical enteropathogenic Escherichia coli strains expressing the localized adherence-like pattern in HEp-2 cells. J Clin Microbiol. 2010;48:302-6. 
36. Lacher DW, Steinsland H, Blank TE, Donnenberg MS, Whittam TS. Molecular evolution of typical enteropathogenic Escherichia coli: clonal analysis by multilocus sequence typing and virulence gene allelic profiling. J Bacteriol. 2007;189:342-50

37. Leverton LQ, Kaper JB. Temporal expression of enteropathogenic Escherichia coli virulence genes in an in vitro model of infection. Infect Immun. 2005;73:1034-43.

Submit your next manuscript to BioMed Central and take full advantage of:

- Convenient online submission

- Thorough peer review

- No space constraints or color figure charges

- Immediate publication on acceptance

- Inclusion in PubMed, CAS, Scopus and Google Scholar

- Research which is freely available for redistribution 